\title{
Did the Romans introduce the Egyptian mongoose (Herpestes ichneumon) into the Iberian Peninsula?
}

\author{
Cleia Detry ${ }^{1}$ (D) João Luís Cardoso ${ }^{1,2,3}$ • Javier Heras Mora ${ }^{4}$ - Macarena Bustamante-Álvarez ${ }^{5}$ Ana Maria Silva ${ }^{1,6}$. \\ João Pimenta $^{1,7} \cdot$ Isabel Fernandes ${ }^{8} \cdot$ Carlos Fernandes $^{9}$
}

Received: 19 June 2018 / Revised: 23 August 2018 / Accepted: 19 September 2018

(C) Springer-Verlag GmbH Germany, part of Springer Nature 2018

\begin{abstract}
New finds of bones of the Egyptian Mongoose (Herpestes ichneumon), one from Portugal and one from Spain, were directly ${ }^{14} \mathrm{C}$ dated to the first century AD. While the Portuguese specimen was found without connection to the Chalcolithic occupation of the Pedra Furada cave where it was recovered, the Spanish find, collected in the city of Mérida, comes from a ritual pit that also contained three human and 40 dog burials. The finds reported here show that the Egyptian mongoose, contrary to the traditional and predominant view, did not first arrive in the Iberian Peninsula during the Muslim occupation of Iberia. Instead, our findings are consistent with the hypothesis that the species was first introduced by the Romans, or at least sometime during the Roman occupation of Hispania. Therefore, radiocarbon dating of new archaeological finds of bones of the Egyptian Mongoose (Herpestes ichneumon) in the Iberian Peninsula push back the confirmed presence of the species in the region by approximately eight centuries, as the previously oldest dated record is from the ninth century. With these new dates, there are now a total of four ${ }^{14} \mathrm{C}$ dated specimens of Egyptian mongooses from the Iberian Peninsula, and all of these dates fall within the last 2000 years. This offers support for the hypothesis that the presence of the species in Iberia is due to historical introductions and is at odds with a scenario of natural sweepstake dispersal across the Straits of Gibraltar in the Late Pleistocene (126,000-11,700 years ago), recently proposed based on genetic data.
\end{abstract}

Keywords Egyptian mongoose $\cdot$ Herpestes ichneumon $\cdot$ Iberia $\cdot$ Roman period

Communicated by: Sven Thatje

Cleia Detry

cdetry@gmail.com

1 UNIARQ Centro de Arqueologia da Universidade de Lisboa, Faculdade de Letras da Universidade de Lisboa, Lisbon, Portugal

2 Universidade Aberta, Lisbon, Portugal

3 ICArEHB, Faculdade das Ciências Humanas e Sociais, Universidade do Algarve, Faro, Portugal

4 Junta de Extremadura, Extremadura, Spain

5 Departamento de Prehistoria y Arqueología. Facultad de Filosofia y Letras, Universidad de Granada, Granada, Spain

6 Laboratório de Préhistória, CIAS Centro de Investigação em Antropologia e Saúde, Departamento Ciências da Vida, Universidade de Coimbra, Coimbra, Portugal

7 Município de Vila Franca de Xira, Vila Franca de Xira, Portugal

8 Município de Palmela, Palmela, Portugal

9 CE3C-Centre for Ecology, Evolution and Environmental Changes, Faculdade de Ciências da Universidade de Lisboa, Lisbon, Portugal

\section{Introduction}

The origin of the Iberian population of the Egyptian mongoose (Herpestes ichneumon) has been much debated. Zooarchaeology can play an important role in clarifying when and how this species reached the Iberian Peninsula.

Today, this mammalian mesocarnivore is found mainly in Africa and southwest Asia (Do Linh San et al. 2016). In Europe, its distribution is restricted to the southwestern part of the Iberian Peninsula (Delibes 1982; Balmori and Carbonell 2012; Fig. 1).

The distribution of the Egyptian mongoose in the Iberian Peninsula may have experienced expansions and contractions, with the species now undergoing a period of expansion and recolonization (Borralho et al. 1996; Balmori and Carbonell 2012; Barros et al. 2015). The fact that the mongoose inhabits Mediterranean forest and shrublands and prefers dense vegetation cover, coupled with the reduction of these biotopes due to agricultural expansion in the twentieth century, may explain the shrinkage of the species' range during that period (Delibes 
1982; Borralho et al. 1996). Throughout much of the last century, the mongoose was restricted to the south of the Tagus River, whereas in the nineteenth century, the Iberian range was more extensive and included some of the northernmost regions of the peninsula, such as Galicia and Asturias (Delibes 1982). It is possible that before the nineteenth century, with lower human pressure, the Egyptian mongoose could have been distributed across the Iberian Peninsula. However, there are probably factors, such as lower temperatures (Barros et al. 2015), that limit the spread and persistence of the species in the north, and the Pyrenees apparently act as a barrier to dispersal outside the peninsula.

While the Egyptian mongoose is known from the Late Pleistocene and Holocene of north Africa, it is absent in the European Pleistocene fossil record (Kurtén 1968; Dobson 1998). Accordingly, its presence in the Iberian Peninsula is generally considered the result of historical introduction from north Africa (Dobson 1998), and traditionally linked to the Arab conquest of Iberia (Delibes 1982).

Before this study, three archaeological finds of Egyptian mongoose from Iberia were published. One from Nerja Cave in southern Spain, radiocarbon dated to the twelfth century AD (Riquelme-Cantal et al. 2008), and another from Muge in central Portugal, ${ }^{14} \mathrm{C}$ dated to the ninth century $\mathrm{AD}$. These were consistent with the hypothesis of introduction(s) during the Muslim occupation of the Iberian Peninsula (Detry et al. 2011). More recently, remains of the mongoose have been found well to the north of its present-day range, in Gijón, northern Spain, and dated to the sixth century $\mathrm{AD}$ (Llorente-Rodríguez et al. 2015) (Fig. 1).

Here, we report additional remains of Egyptian mongoose from Portugal and Spain, two of which were ${ }^{14} \mathrm{C}$ dated to the Roman period (Table 1; Fig. 1). The Spanish set of remains (Fig. 2) was dated to the first century AD and found together with $40 \operatorname{dogs}$ in a ritual context in Mérida (Calle Almendralejo), western Spain. The radiocarbon-dated bone from Portugal (Fig. 3), also dated to the first century AD, was found intrusive (i.e. not contemporaneous with the prehistoric human occupation) in a Chalcolithic context in the Cave of Pedra Furada in Vila Franca de Xira. The three remaining bones (Fig. 4) were found in Islamic contexts in the
Fig. 1 Map showing the geographic range (grey colour) of the Egyptian mongoose (Herpestes ichneumon) in the Iberian Peninsula until 2010 (Barros et al. 2015; Balmori and Carbonell 2012). Black dots and stars, respectively, indicate the location of previously published and new finds (this study) of H. ichneumon. 1-Fábrica de Tabacos, Gijón, Spain; 2-Moita do Sebastião, Muge, Portugal; 3 Cabeço da Amoreira, Muge, Portugal; 4 Pedra Furada 1 Cave, Vila Franca de Xira, Portugal; 5Calle (street) Almendralejo, 41, Mérida, Spain; 6-Ponta da Passadeira, Barreiro, Portugal; 7 Palmela Castle, Palmela, Portugal; 8-Nerja Cave, Málaga, Spain. Map done by André Pereira

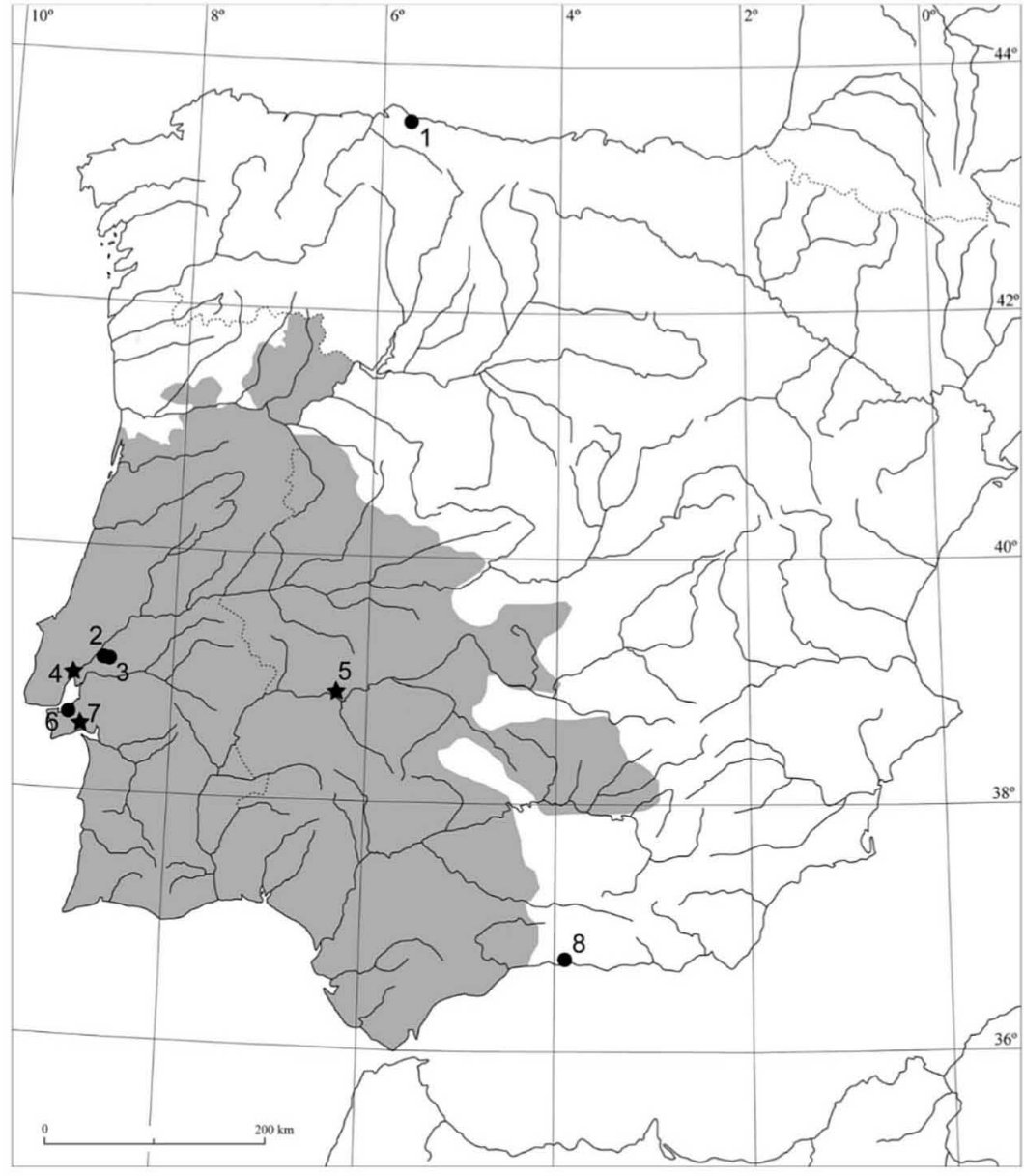




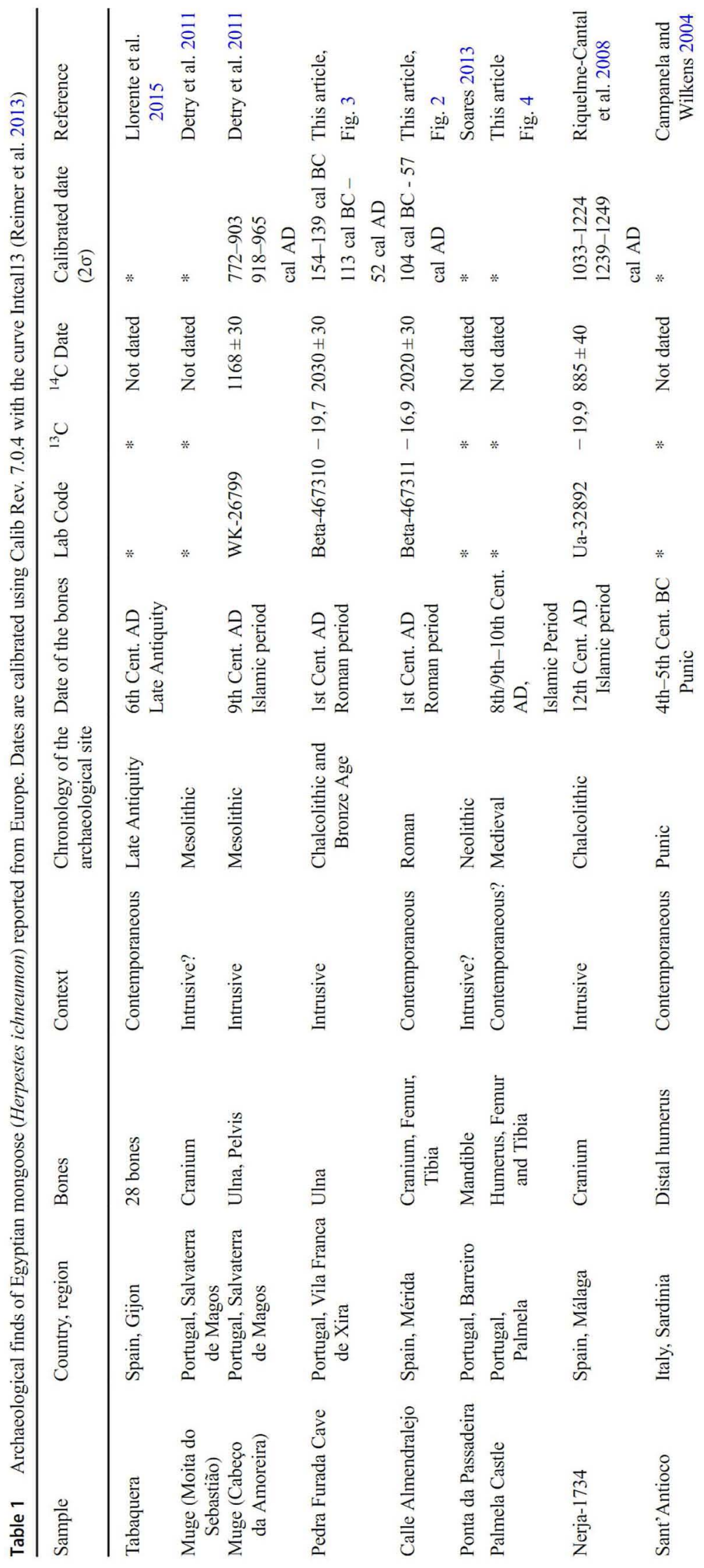


Fig. 2 Bones of Egyptian mongoose (Herpestes ichneumon) found in the funerary pit at Calle Almendralejo, Mérida (Spain) (on the left), compared with the bones of the LARCDGPC reference collection (right). Photographs: José Paulo Ruas
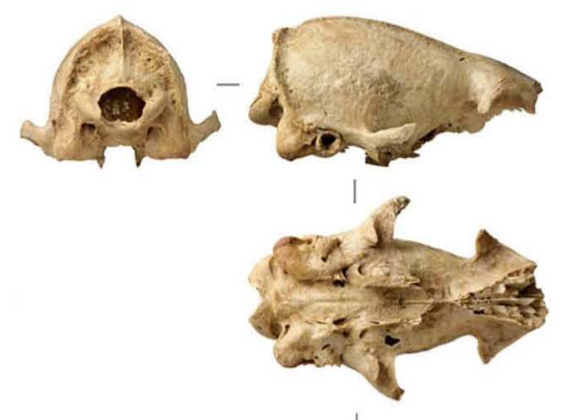

।
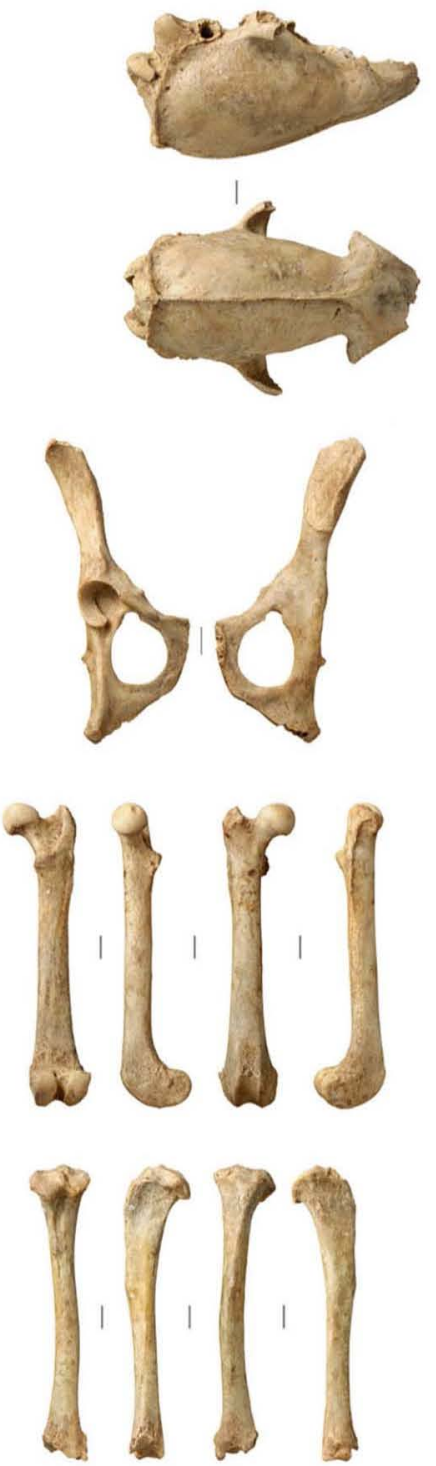
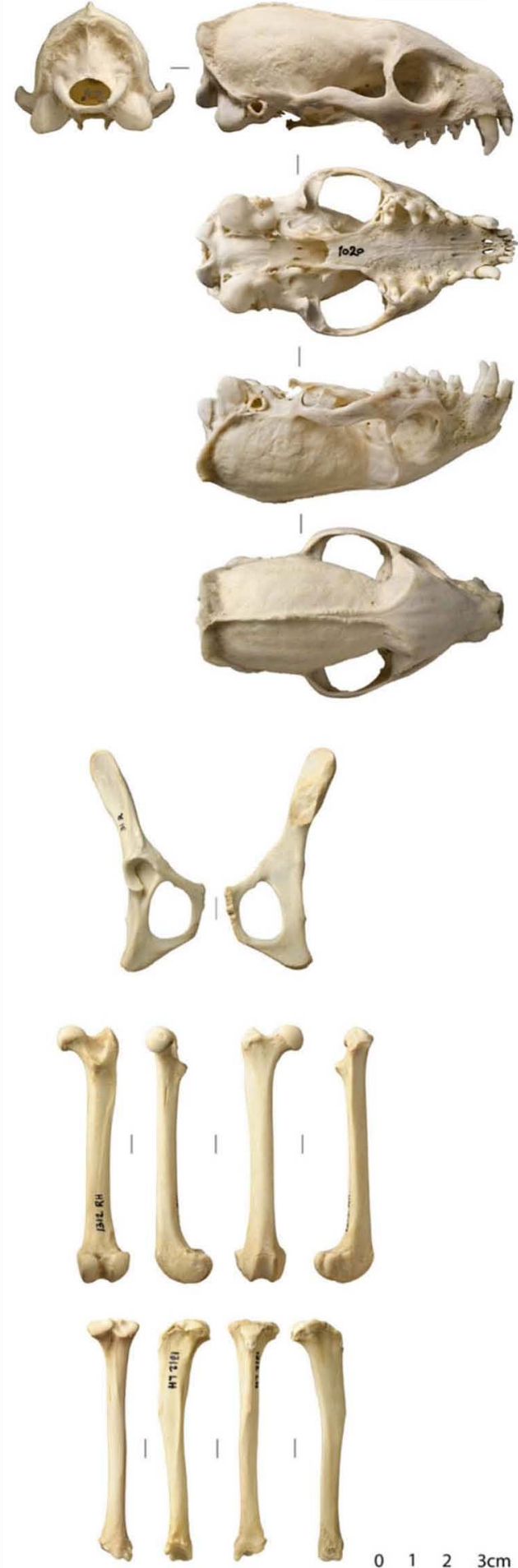

$\begin{array}{llll}0 & 1 & 2 & 3 \mathrm{~cm}\end{array}$ medieval site of the Castle of Palmela, Portugal, and dated via the associated cultural remains.

The finds discussed here are therefore the oldest radiocarbon-dated remains of Egyptian mongoose described so far for the Iberian Peninsula.

\section{Archaeological remains of the Egyptian mongoose in Europe}

It has been argued (Masseti 2009) that the earliest find of the Egyptian mongoose in Europe is a bone recovered from a 
Fig. 3 One ulna identified as Egyptian mongoose (Herpestes ichneumon) from Pedra Furada Cave (Portugal) (on the left), compared with the bones of the LARC-DGPC reference collection (right), radiocarbon dated to the first century AD. Photographs: José Paulo Ruas
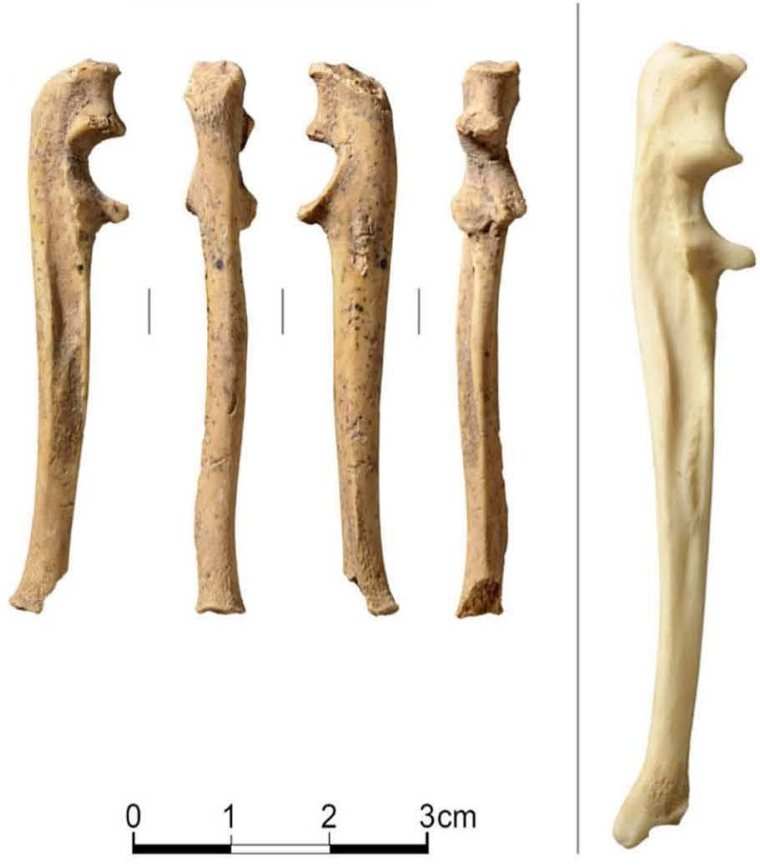
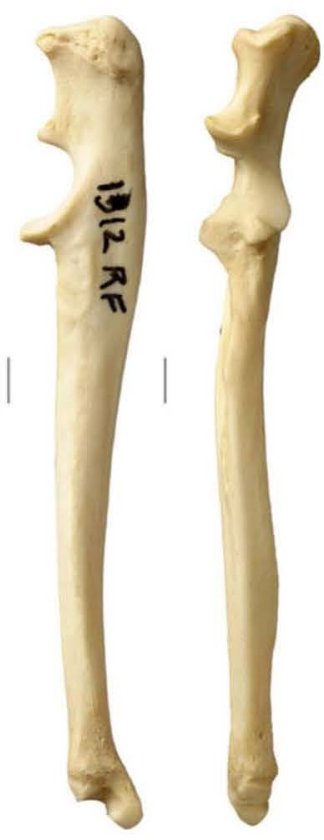

Punic cistern dated to the 5th-4th century BC in Sant'Antioco Island, Sardinia (Campanella and Wilkens 2004). However, this is a debatable assertion, given the possibility of stratigraphic uncertainty (e.g. Riquelme-Cantal et al. 2008). Masseti (2009) convincingly makes the case that the bone probably belonged to a tamed or domestic animal kept for controlling rodents. The fact that the bone was found in a closed deposit makes it likely that it was intentionally deposited.

The second published find from Europe, and the first from the Iberian Peninsula, was unearthed in Nerja Cave (RiquelmeCantal et al. 2008). Only one complete cranium was found, but its good preservation facilitated its identification to species. The layer from which it was recovered was culturally dated to the Bronze Age, but a direct radiocarbon date on the specimen showed that it in fact belonged to a much later period, the twelfth century AD. Nerja cave was occupied intermittently during the medieval period, including the Islamic one.

More recently, in the Mesolithic shell middens of Muge, we found four bones of H. ichneumon: one cranium in Moita do Sebastião, and one pelvis and two complete right ulnae in Cabeço da Amoreira (Detry et al. 2011). One of the ulnae was radiocarbon dated to the ninth century $\mathrm{AD}$, making it contemporary with the Umayyad Emirate of Cordoba, in the early phase of the Islamic occupation of Iberia during medieval times.

The latest published find of $H$. ichneumon in Europe comes from a site in Gijón (La Fábrica de Tabacos), a location outside the current distribution range, and has been dated to the sixth or seventh century AD (Llorente-Rodríguez et al. 2015). It is the most complete skeleton among the European remains of the species, including 28 bones that are very well preserved due to the low-oxygen content of the soil. They also do not show any signs of having been eaten or prepared in any way (Llorente-Rodríguez et al. 2015). The stratigraphic unit in which they were found also contained an abundance of pet animals such as cats and dogs, and this raises the possibility that the mongoose was also a pet (Llorente-Rodriguez et al. 2015). Gijón is not within the current distribution range of the species, but might have been in the past, with several authors reporting its presence in northern Spain. Gijón was also an important port in Late Antiquity (Fernandez-Ochoa et al. 2015).

There is also an undated isolated mandible found at the Neolithic open-air site of Ponta da Passadeira (Barreiro, Portugal) (Soares 2013). It is possible that this specimen is intrusive since it came from an unsealed context in this open-air site.

New evidence for the presence of the Egyptian mongoose in Roman Iberia (Vila Franca de Xira and Mérida) and Medieval Portugal (Palmela) is described in the "Results" section.

Table 1 presents a summary of the archaeological remains of H. ichneumon in Europe and see Detry et al. (2011) for a brief review of the paleontological and archaeological records of the species from elsewhere.

\section{Methods}

The mongoose remains reported in this study were found in general zooarchaeological surveys at the three archaeological sites. Of the bones collected, those of small carnivores were 
Fig. 4 Bones identified as Egyptian mongoose (Herpestes ichneumon) from Palmela castle (Portugal) (on the left), compared with the bones of the LARCDGPC reference collection (right). The archaeological context was dated to the 8 th- 10 th century AD. Photographs: José Paulo Ruas
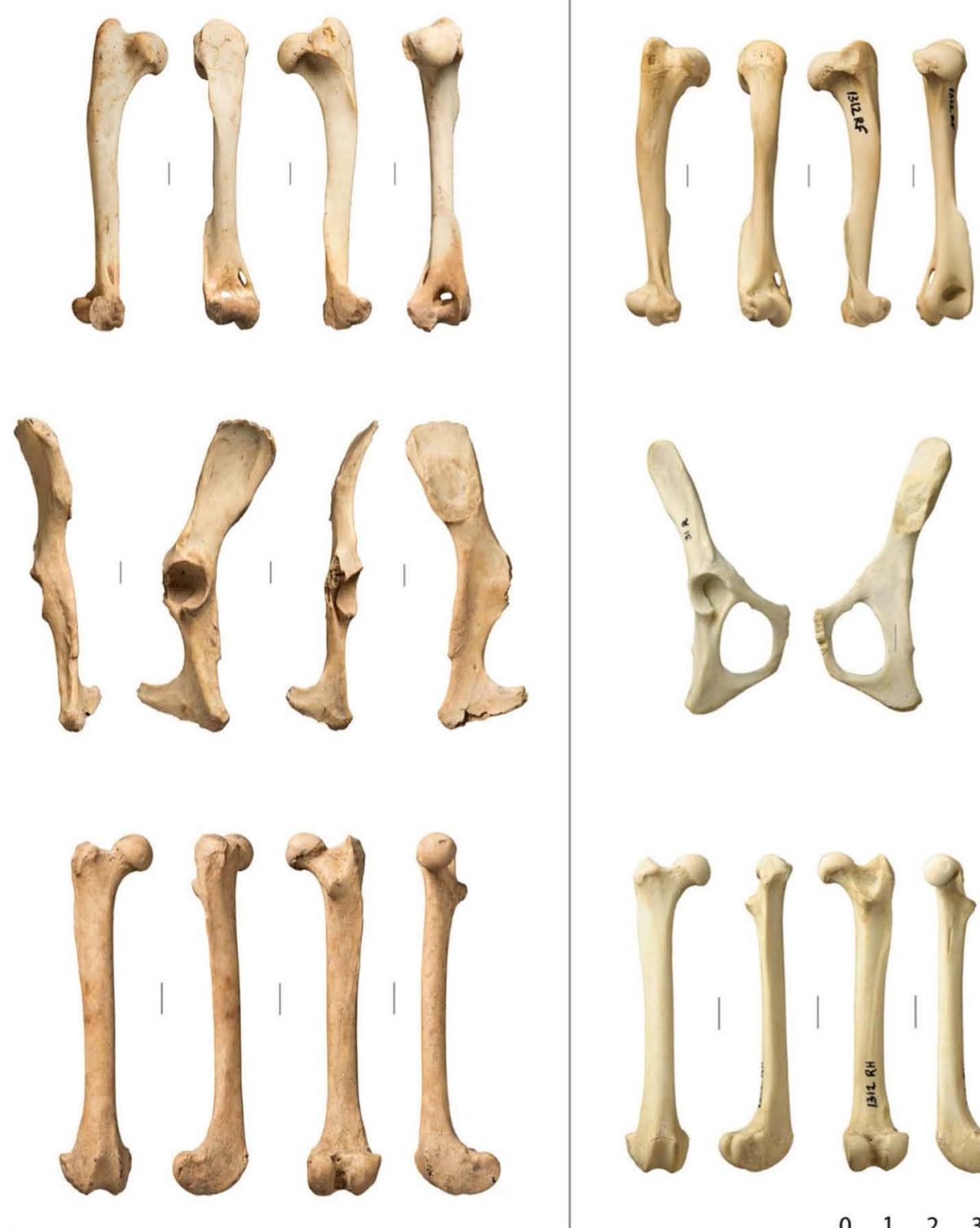
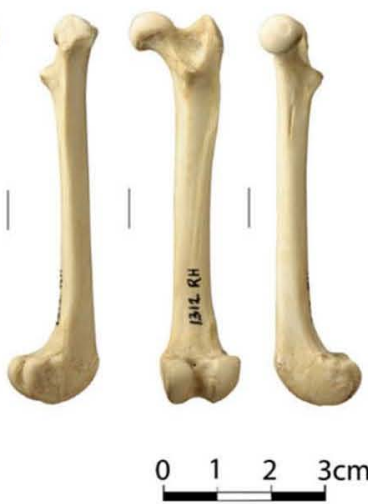

compared with the reference collection of the Archaeosciences Laboratory of Lisbon (Direcção Geral do Património Cultural). Of the bones identified as belonging to $H$. ichneumon, a sample of $2 \mathrm{~g}$ from the Cave of Pedra Furada ulna and of the Mérida specimen (tibia) were sent to Beta Analytic Inc. for radiocarbon dating. The protocol involved a pre-treatment of the bone samples with cold HCL to eliminate the mineral fraction and extract the collagen, which is the portion needed for radiocarbon dating. To ensure removal of secondary organic acids, the collagen was washed with an alkali solution. The samples were then converted into graphite for accelerator mass spectrometry (AMS) analysis and the ratios of ${ }^{14} \mathrm{C},{ }^{13} \mathrm{C}$ and ${ }^{12} \mathrm{C}$ were measured. We used AMS because it is the method of choice for radiocarbon measurements due to its accuracy and requiring a much smaller sample than radiometric techniques (Wood 2015). The d13C values were measured separately in an isotope ratio mass spectrometer (IRMS). The ${ }^{14} \mathrm{C}$ dates were then calibrated using Calib REV 7.0.4 and the Intcal13 curve (Reimer et al. 2013) (Table 1).

\section{Results}

The remains studied here come from three different sites: a ritual pit in Emerita Augusta (modern Mérida), the Roman capital of Lusitania; a cave with prehistoric occupation close to the Tagus estuary (Gruta da Pedra Furada); and the medieval castle of Palmela, in the Setúbal Peninsula between the Tagus and Sado estuaries (Fig. 1). 


\section{Emerita Augusta (Calle Almendralejo)}

Between 2005 and 2007, emergency excavations were undertaken at number 41, Calle Almendralejo, near the north Gate of Emerita Augusta. At this location, a large Roman dump was uncovered, containing remains dating close to the foundation of the city, at the end of first century AD to the fifth century AD (Bustamante-Álvarez 2013; Heras Mora et al. 2011, 2017). In the middle of the site, a large pit was found with evidence that indicate its ritual character, among them, ceramics with a high symbolic content or fine tableware destined for symposia (Heras Mora et al. in press; Heras Mora and Olmedo 2010).

The $H$. ichneumon remains found at the site include a cranium (posterior part without maxilla), a right pelvis, a right femur and one complete left tibia (Fig. 2). All the long bones had completely fused epiphyses, indicating that they belonged to an adult animal. The tibia was directly radiocarbon dated to $104 \mathrm{cal} \mathrm{BC-57} \mathrm{cal}$ AD (Table 1). The remains were discovered in a particular archaeological context, with three human skeletons at the bottom of the pit covered by ca. 40 dog skeletons and the mongoose bones. This assemblage had been sealed with a layer of funerary banquet terra sigillata sudgalica (Bustamante-Álvarez 2009), indicating a date for the pit contents of ca. 50-60 AD. The ${ }^{14} \mathrm{C}$ date is compatible with this supposition. The fact that the context was sealed made it less likely that the remains could have been intrusive.

The mongoose bones may have belonged to the same animal and, as in the case of the specimen from Gijón (LlorenteRodríguez et al. 2015), the fact that it was buried with dogs, many of which were small lap-dogs (Pires et al. 2017), suggests that it could also have been a pet.

\section{Gruta da Pedra Furada}

Pedra Furada are two caves located on a slope near Vila Franca de Xira, a town $40 \mathrm{~km}$ northeast of Lisbon. In the first cave (Gruta da Pedra Furada 1), among other faunal remains, we found a left ulna of Egyptian mongoose (Fig. 3). The cave had an intermittent late Chalcolithic and Bronze Age occupation and was also used in the early modern period (fifteenth century AD). In prehistoric times, the site was mainly used for burials and the skeletons of some 34 or more humans have been found. Only one human bone was directly radiocarbon dated, and the estimated date fell in the 4th/3rd millennium BC (Silva et al. 2014), thus compatible with a Chalcolithic occupation. No Roman remains were found in the cave. It was excavated in the 1950s and the faunal remains were recently studied by Cardoso and Detry (see Silva et al. 2014). Among the remains were domestic species such as cattle, sheep, goat and pig. Most are interpreted as burial offerings as was then customary. A few bones of chicken may indicate a more recent occupation, as the chicken is known in Portugal mainly since the Iron Age (Davis 2007).

The Egyptian mongoose ulna has an unfused olecranon, indicating a juvenile individual. The ulna was ${ }^{14} \mathrm{C}$ dated yielding a $2 \sigma$ interval of $154 \mathrm{cal} \mathrm{BC}-52 \mathrm{cal} \mathrm{AD}$ (Table 1), and hence its presence is unconnected with the human occupation of the cave. During the long interval between the Bronze Age and modern times, the cave was unoccupied and would naturally have been used by wild animals such as the mongoose. The recovered specimen, in contrast to the remains from Emerita Augusta, is intrusive and most certainly belonged to a wild animal.

\section{Palmela Castle}

Palmela castle in the town of Palmela, $40 \mathrm{~km}$ southeast of Lisbon, is an important fortress - occupied since the earliest Muslim presence in Iberia - the end of the eighth century/first half of the ninth century AD (Fernandes 2004).

In one of the excavated galleries, in the oldest deposits, three very well-preserved bones - a left humerus, a left pelvis and a right femur-were recovered (Fig. 4). The context is dated, through the materials recovered, between the 8 th/9th and the 10th centuries AD. The mongoose remains could not have been introduced before the construction of the castle, and they are possibly coeval with the first Islamic occupation, when the castle was built.

\section{Radiocarbon dating}

Direct radiocarbon dating is particularly useful in the case of burrowing animals, since this behaviour increases the likelihood that their remains are intrusive into archaeological layers. For the Egyptian mongoose, this concern is reinforced by remains that yielded radiocarbon dates much younger than the archaeological layers in which they were recovered (Riquelme Cantal et al. Riquelme-Cantal et al. 2008; Detry et al. 2011).

Two of the bones described here, one tibia from Emerita Augusta and one ulna from Gruta da Pedra Furada, were sent in 2017 to Beta Analytic Inc. and both produced dates contemporaneous with the beginning of the Romanization of Hispania after its conquest. The overlap between the two estimated dates (Beta-467310 and Beta-467311) was a complete surprise since the two bones come from very different sites hundreds of kilometres apart. The different ${ }^{13} \mathrm{C}$ values confirmed that the bones were from different individuals with different diets. This rules out the possibility that the similarity of the two estimates could be due to sample mixing or crosscontamination in the laboratory before analysis.

The remains from Palmela Castle were not ${ }^{14} \mathrm{C}$ dated because they could not be older than the end of the eighth century $\mathrm{AD}$ or the first half of the ninth century, when the castle 
was built, and thus cannot set an earlier date for the arrival of the Egyptian mongoose in the Iberian Peninsula than that already established by the two bones radiocarbon dated in this study (first century AD).

\section{Discussion}

There is currently no evidence that the Egyptian mongoose has ever been truly domesticated, in the sense of selective breeding across multiple generations leading to permanent genetic modification (Driscoll et al. 2009). Nevertheless, it is known that the species can be tamed and bred as a household pet (Harrison 1968; Osborn and Helmy 1980; Ben-Yaacov and Yom-Tov 1983; Evans 2016) and has historically been used for rodent control (Faure and Kitchener 2009; Masseti 2009). This latter purpose has been suggested as the main reason for the introduction of the Egyptian mongoose in the Iberian Peninsula (Faure and Kitchener 2009; Masseti 2009; Detry et al. 2011). As noted by Masseti (2009), the reality of ancient introductions of the species to Europe is attested by the bone from Sant'Antioco Island. Ancient introductions to Sicily and the Italian Peninsula in late Antiquity or medieval times also likely explain the early presence of another African mammal, the crested porcupine Hystrix cristata, probably for pharmaceutical purposes (Masseti et al. 2010).

Recently, based on the results of a genetic study, it has been postulated that the Egyptian mongoose entered the Iberian Peninsula by natural sweepstake dispersal across the Strait of Gibraltar sometime during the Middle to Late Pleistocene cyclic lowering of sea level (Gaubert et al. 2011; Gaubert 2016).

The Strait of Gibraltar has been open since the end of the Messinian salinity crisis at the Miocene-Pliocene transition, ca. 5.3 million years ago (Krijgsman et al. 1999; Blanc 2002; Loget and Van Den Driessche 2006). Importantly, while the earliest fossils assigned to Herpestes are from the Middle Miocene (ca. 14.5 Ma; Tugen Hills, Kenya; Morales and Pickford 2008) and Late Miocene (9.5-7 Ma; Siwaliks, Pakistan; Barry 1983) (ca. 7 Ma; Toros-Menalla, Chad; Peigné et al. 2008), H. ichneumon is first known from the mid-Pliocene Upper Laetolil Beds (3.85-3.63 Ma; Deino 2012) at Laetoli, northern Tanzania (Petter 1987; Werdelin and Dehghani 2011). The Egyptian mongoose has also been reported from the early Middle Pleistocene of Asbole, Ethiopia (Geraads et al. 2004) and from the Early Pleistocene site of Ubeidiya, Israel (Belmaker 2010).

In northwestern Africa, the species is found from the Middle Pleistocene onwards (Geraads 2008; Geraads et al. 2010; Raynal et al. 2010). Thus, the species apparently did not exist, or at least did not occur in north Africa, before the opening of the Strait of Gibraltar, ruling out the scenario of dry-land crossing of the Mediterranean. However, it seems unlikely that the Iberian population of $H$. ichneumon is derived from westward dispersal from the Middle East across Southern Europe, given the current absence of prehistoric remains of the species in Europe.

Since the opening of the Strait of Gibraltar, sea level in the strait was lowest $30 \mathrm{ka}$ and $26-17 \mathrm{ka}$ ago, when it was about $125 \mathrm{~m}$, and at most $150 \mathrm{~m}$, below present sea level (Rohling et al. 2014). On the west side of the strait, the Camarinal Sill, the shallowest sill separating the Mediterranean Sea from the Atlantic Ocean, has a present depth of $284 \mathrm{~m}$ (Blanc 2002). Paleogeographic reconstructions indicate that the minimum width of the strait in the Pleistocene would have been $8-10 \mathrm{~km}$ (Shackleton et al. 1984; Collina-Girard 2001; Gutscher 2005; Gracia et al. 2008). To the west of the Camarinal Sill, where the strait widens, some presently submerged small islands and islets, including the Spartel Bank, would have appeared whenever sea level fell $100-130 \mathrm{~m}$ below its present level (CollinaGirard 2001), while remaining separated by deep channels (Blanc 2002). The use of these islands as stepping stones for dispersal across the strait would have required at least two hops, one of them involving a distance over water of no less than 6-7 km (Collina-Girard 2001; Gracia et al. 2008; Linstädter et al. 2012). Moreover, during cold periods such as the last glacial maximum (LGM, 26.5-19 ka ago; Clark et al. 2009), marine surface currents flowing westwards (Gibert et al. 2003) would tend to carry dispersing animals, either swimming or on natural rafts, into the Atlantic and not across the strait. Vegetation rafts, unlike in the tropics, are not a typical feature of the Mediterranean today, and probably were not during the Pleistocene (Broodbank 2006). Accordingly, the palaeontological and zoogeographical data indicate that the Strait of Gibraltar has been an effective barrier to a large number of land animal species (O'Regan 2008), and of those that have crossed several result from human introductions (Dobson 1998; Cosson et al. 2005; Modolo et al. 2005; Lalis et al. 2016). Palaeontological evidence of the native presence of a species on both sides of the Strait in the Plio-Pleistocene does not necessarily imply sea crossings, since it could also be due to migration around both shores of the Mediterranean (O'Regan 2008). Among those species that could plausibly have crossed the Strait are large mammals with good swimming abilities, such as bears, deer, and possibly boar and hippopotamus (Dobson 1998; O'Regan 2008; Geraads 2010; Palombo 2014; Fernandez et al. 2015; Soria-Boix et al. 2017). It is therefore clear that the Strait has acted as a strong biogeographic filter, allowing the dispersal of a limited number of species (FerràndezCañadell et al. 2014; Gibert et al. 2016). Besides the Egyptian mongoose, the only other Afrotropical carnivore in the Iberian Peninsula, the common genet (Genetta genetta), is widely considered to have been introduced from north Africa (Morales-Muñiz 1994; Dobson 1998; Gaubert et al. 2011; Gaubert 2016). 
Even archaeological evidence for humans throughout the Pleistocene has been generally interpreted as indicating that trans-Gibraltar contacts only occurred at the end of the Upper Palaeolithic, about 12,000 years ago (Straus 2001; Erlandson 2001; Garcea 2004; Derricourt 2005; Broodbank 2006; Carbonell and Rodríguez 2006; Alcaraz Castaño 2007; van der Made 2011; Linstädter et al. 2012; Garcia et al. 2013; Croitor 2018; Muttoni et al. 2018), presumably by boat since by this time, sea level was similar to the present (Rohling et al. 2014). Only recently, evidence has been accumulating to suggest that the Iberian Acheulean, a type of human lithic industry, may have originated in north Africa through contact across the Strait of Gibraltar during the early Middle Pleistocene (Santonja and Pérez-González 2010; Jiménez-Arenas et al. 2011; Sharon 2011; Sharon and Barsky 2016; Santonja et al. 2016; Álvarez-Posada et al. 2017; but see also Rolland 2013 and Walker et al. 2013). Nevertheless, the apparent overall rarity of trans-Gibraltar human movements in the Pleistocene reinforces the idea that the Strait is a strong barrier to dispersal of land mammals.

Gaubert et al. (2011) proposed the hypothesis that the Egyptian mongoose reached the Iberian Peninsula via a sweepstake crossing of the Strait of Gibraltar sometime during the Middle to Late Pleistocene, based mainly on the following results of their genetic study: (i) an observed high mitochondrial DNA (mtDNA) differentiation between population samples from Iberia and northwest Africa and (ii) the level of mtDNA diversity in the Iberian sample, which was considered high by the authors. However, sample sizes were unbalanced between Iberia and northwest Africa, being very small for Morocco $(n=3)$ and Algeria $(n=7)$. It is well known that comparisons of mtDNA diversity between populations or regions are highly sensitive to undersampling (GoodallCopestake et al. 2012; Phillips et al. 2015). Small and unbalanced sample sizes can also lead to biased estimates of genetic differentiation due to sampling error on allele frequencies (Holsinger and Weir 2009; Caujapé-Castells 2010), and this bias is particularly likely with a single locus such as mtDNA. Insufficient sampling in northwest Africa may have missed haplotypes shared with the Iberian Peninsula if they are currently infrequent in the former region. In such cases, it has been shown that inadequate sampling can strongly influence results and interpretations on the origin of extralimital populations (Cristescu et al. 2001; Hänfling et al. 2002; Muirhead et al. 2008; Johnson et al. 2011).

The new dated finds reported here, taken together with dates from previous studies (Riquelme-Cantal et al. 2008; Detry et al. 2011; Llorente-Rodríguez et al. 2015), strongly support the hypothesis that the presence of the Egyptian mongoose in the Iberian Peninsula is due to historical introductions. As previously remarked by Detry et al. (2011), if as proposed by Gaubert et al. (2011) the species had arrived in the Iberian Peninsula sometime in the Middle to Late
Pleistocene, it is striking that none of the dated remains of Iberian H. ichneumon are prehistoric (Table 1).

Some of the remains (Emerita Augusta and Gijón) were contemporaneous with the archaeological contexts in which they were found and may represent pets that were intentionally buried. It might be argued that the age and context of these specimens, since they could have been pets, do not necessarily bear on the age and origin of the wild population in the Iberian Peninsula. However, this caveat does not apply to the remains from Nerja, Muge and Gruta da Pedra Furada, which were all shown by direct radiocarbon dating to be intrusive. These intrusive remains are likely the result of burrowing behaviour (Palomares and Delibes 1993), and therefore most probably belonged to individuals living in the wild.

The dated $H$. ichneumon remains from Europe reported so far seem to suggest an interesting pattern, which may apply to other burrowing animals that could have been tamed, kept as pets or venerated in some way. On one hand, there are specimens, often isolated bones, shown to be intrusive by radiocarbon dating and recovered from archaeological contexts (much) older than the age of the remains, which probably belonged to wild individuals that died in their burrows. On the other hand, there are finds, in some cases of several bones, coming from sealed loci and ritual burials, and dated as contemporaneous with the contexts in which they were found, which likely represent pet or tame animals.

Here, we present two assemblages representing these two depositional types, and both dated to the first century AD. They unambiguously prove the presence of the Egyptian mongoose in Iberia during the Roman period and represent the oldest record of the species in the Iberian Peninsula.

Our findings are thus consistent with the hypothesis that the species was first introduced by the Romans, or at least sometime during the Roman occupation of Hispania. It is well known that during the Roman Republic and Empire, there was a constant movement of people, animals, goods and ideas all over the Mediterranean basin, linking north Africa and the Levant with Southern Europe (Leitch 2013; Scheidel 2014; Colominas and Edwards 2017; Pires et al. 2017). In Emerita Augusta, evidence of a north African connection is illustrated by the presence of African Red Slip Ware from the province of Byzacena (Tunisia) until the sixth century AD, and also the trade of oil amphorae of the same origin (Vázquez de la Cueva 1985). We can also observe a religious connection since the funerary monument where the mongoose was found seems to have a north-African influence (Prados 2008), such as the cupae and tower mausoleums (Bustamante-Álvarez and Olmedo 2012). The ritual sacrifice of dogs, which is probably the case at Calle Almedralejo, is also related to Punic-Hispanic influences and of north-African tradition, as it was interpreted for the necropolis of Gadir (modern Cádiz, Spain) (Niveau and Mariñas 2006; Heras Mora et al. in press). 
As discussed above, the association with dogs suggests that the Egyptian mongoose bones that were recovered from the same site may have belonged to an intentionally buried pet. In this context, it is worth remembering that in ancient Egypt, the mongoose clearly had some religious and emotional significance: it was represented in paintings, collars, statues, burials and was even mummified (Hinton and Dunn 1967; Nicholson et al. 2015; Evans 2016).

\section{Conclusion}

This report increases awareness of the question of the origin of the Egyptian mongoose in the Iberian Peninsula and stimulates further research to shed more light on how and when this mesocarnivore arrived in Iberia. For instance, it would be relevant to obtain radiocarbon dates for the remains in Table 1 not yet absolutely dated.

The findings presented here provide the earliest record of the species in the region and are consistent with a time of first introduction during the Roman occupation of Hispania. Our study therefore offers the first conclusive evidence refuting the traditional and dominant view that the first introduction occurred during the Muslim occupation of Iberia. Moreover, the new dated finds, taken together with dates from previous studies (Riquelme-Cantal et al. 2008; Detry et al. 2011; LlorenteRodríguez et al. 2015), raise the possibility of multiple introductions at different times from Classical Antiquity to the Early Middle Ages.

The Egyptian mongoose bones from Emerita Augusta are notable because they come from an anthropic context, a ritual pit that also contained three human and $40 \mathrm{dog}$ burials, and this leads us to believe that the mongoose bones belonged to a pet, which received the same ritual treatment.

Acknowledgments We thank the Archaeoscience lab of the Portuguese Heritage directorate (LARC-DGPC) for use of their reference collection of modern mammal skeletons, José Paulo Ruas for his excellent photographs, and André Pereira for drafting the map. Finally, we would also like to thank Simon Davis for revising the manuscript and making suggestions.

Funding information UNIARQ (Center of Archaeology, Faculty of Letters of the University of Lisbon) funded the ${ }^{14} \mathrm{C}$ dating, and FCT (Fundação para a Ciência e Tecnologia) funded CD's post-doctorate (grant: SFRH/BPD/108326/2015). CF was supported by FCT, within the project UID/BIA/00329/2013.

\section{References}

Alcaraz Castaño M (2007) El Ateriense del Norte de África y el Solutrense peninsular: $i$ contactos transgibraltareños en el Pleistoceno Superior? Munibe Antropologia-Arkeologia 58:101126
Álvarez-Posada C, Parés JM, Sala R, Viseras C, Pla-Pueyo S (2017) New magnetostratigraphic evidence for the age of Acheulean tools at the archaeo-palaeontological site "Solana del Zamborino"(GuadixBaza Basin, S Spain). Sci Rep 7(1):13495. https://doi.org/10. 1038/s41598-017-14024-5

Balmori A, Carbonell R (2012) Expansion and distribution of the Egyptian mongoose (Herpestes ichneumon) in the Iberian Peninsula. Galemys 24:83-85. https://doi.org/10.7325/ Galemys2012.N08

Barros T, Carvalho J, Pereira MJR, Ferreira JP, Fonseca C (2015) Following the trail: factors underlying the sudden expansion of the egyptian mongoose (Herpestes ichneumon) in Portugal. PLoS One 10(8):e0133768. https://doi.org/10.1371/journal.pone.0133768

Barry JC (1983) Herpestes (Viverridae, Camivora) from the Miocene of Pakistan. J Paleontol 57(1):150-156

Belmaker M (2010) Early Pleistocene faunal connections between Africa and Eurasia: an ecological perspective. In: Out of Africa I. Springer, Dordrecht, pp 183-205

Ben-Yaacov R, Yom-Tov Y (1983) On the biology of the Egyptian mongoose, Herpestes ichneumon, in Israel. Zeitschrift für Säugetierkunde 48(1):34-45

Blanc PL (2002) The opening of the Plio-quaternary Gibraltar Strait: assessing the size of a cataclysm. Geodin Acta 15(5-6):303-317. https://doi.org/10.1080/09853111.2002.10510763

Borralho R, Rego F, Palomares F, Hora A (1996) The distribution of the Egyptian mongoose Herpestes ichneumon (L.) in Portugal. Mammal Rev 26:1-8. https://doi.org/10.1111/j.1365-2907.1996. tb00143.x

Broodbank C (2006) The origins and early development of Mediterranean maritime activity. J Mediterr Archaeol 19(2):199 230

Bustamante-Álvarez M (2009) La terra sigillata Gálica en Augusta Emerita (Mérida, Badajoz). Saguntum 41:149-173

Bustamante-Álvarez M (2013) La terra sigillata hispánica en Augusta Emerita: estudio tipocronológico a partir de los vertederos del suburbio norte. Anejos de AEspA, LXV, Mérida

Bustamante-Álvarez M, Olmedo A (2012) De las "cupae" emeritenses: nuevos datos estratigráficos. In Andreu J (ed) Las cupae hispanas origen, difusión, uso, tipología, UNED, pp 369-392

Campanella L, Wilkens B (2004) Una mangusta egiziana ('Herpestes Ichneumon') dall abitato fenicio di Sant Antioco. Riv Stud Fenici 32(1):25-48

Carbonell E, Rodríguez XP (2006) The first human settlement of Mediterranean Europe. Comptes Rendus Palevol 5(1-2):291-298. https://doi.org/10.1016/j.crpv.2005.12.002

Caujapé-Castells J (2010) General G ST and $\theta$ inflation due to biased intra-population sampling, and its consequences for the conservation of the Canarian Flora. Conserv Genet 11(3):709-720. https:// doi.org/10.1007/s10592-009-9842-z

Clark PU, Dyke AS, Shakun JD, Carlson AE, Clark J, Wohlfarth B, Mitrovica JX, Hostetler SW, McCabe AM (2009) The last glacial maximum. Science 325(5941):710-714. https://doi.org/10.1126/ science. 1172873

Collina-Girard J (2001) L'Atlantide devant le détroit de Gibraltar? Mythe et géologie. C. R.Acad Sci Ser IIA Earth Planet Sci 333(4):233-240. https://doi.org/10.1016/S1251-8050(01)01629-9

Colominas L, Edwards CJ (2017) Livestock trade during the early Roman period: first clues from the trading post of Empúries (Catalonia). Int J Osteoarchaeol 27(2):167-179. https://doi.org/10.1002/oa.2527

Cosson JF, Hutterer R, Libois R, Sara M, Taberlet P, Vogel P (2005) Phylogeographical footprints of the strait of Gibraltar and quaternary climatic fluctuations in the western Mediterranean: a case study with the greater white-toothed shrew, Crocidura russula (Mammalia: Soricidae). Mol Ecol 14(4):1151-1162. https://doi.org/10.1111/j. 1365-294X.2005.02476.x 
Cristescu ME, Hebert PD, Witt JD, MacIsaac HJ, Grigorovich IA (2001) An invasion history for Cercopagis pengoi based on mitochondrial gene sequences. Limnol Oceanogr 46(2):224-229. https://doi.org/ 10.4319/lo.2001.46.2.0224

Croitor R (2018) Paleobiogeography of early human dispersal in western Eurasia: preliminary results. Comptes Rendus Palevol 17(4-5):276 286. https://doi.org/10.1016/j.crpv.2017.09.004

Davis SJ (2007) The mammals and birds from the Iron Age and Roman periods of Castro Marim, Algarve, Portugal. Trabalhos do CIPA, 107. Instituto Português de Arqueologia, Lisboa

Deino AL (2012) 40Ar/39Ar dating of bed I, Olduvai Gorge, Tanzania, and the chronology of early Pleistocene climate change. J Hum Evol 63(2):251-273. https://doi.org/10.1016/j.jhevol.2012.05.004

Delibes M (1982) Notas sobre la distribución pasada y actual del meloncillo Herpestes ichneumon (L.) en la Península Ibérica. Doñana Acta Vertebrata 9:341-352

Derricourt R (2005) Getting "out of Africa": sea crossings, land crossings and culture in the hominin migrations. J World Prehist 19(2):119 132. https://doi.org/10.1007/s10963-006-9002-z

Detry C, Bicho N, Fernandes H, Fernandes C (2011) The emirate of Córdoba (756-929 AD) and the introduction of the Egyptian mongoose (Herpestes ichneumon) in Iberia: the remains from Muge, Portugal. J Archaeol Sci 38(12):3518-3523. https://doi.org/10. 1016/j.jas.2011.08.014

Do Linh San E, Maddock AH, Gaubert P, Palomares F (2016) Herpestes ichneumon. The IUCN red list of threatened species 2016: e.T41613A45207211. doi: https://doi.org/10.2305/IUCN.UK. 2016-1.RLTS.T41613A45207211.en. Accessed 29 May 2018

Dobson M (1998) Mammal distributions in the western Mediterranean: the role of human intervention. Mammal Rev 28(2):77-88. https:// doi.org/10.1046/j.1365-2907.1998.00027.x

Driscoll CA, Macdonald DW, O'Brien SJ (2009) From wild animals to domestic pets, an evolutionary view of domestication. Proc Natl Acad Sci 106(Supplement 1):9971-9978. https://doi.org/10.1073/ pnas.0901586106

Erlandson JM (2001) The archaeology of aquatic adaptations: paradigms for a new millennium. J Archaeol Res 9(4):287-350. https://doi.org/ 10.1023/A: 1013062712695

Evans L (2016) Beasts and beliefs at Beni Hassan: a preliminary report. J Am Res Center Egypt 52:219-229 http://lockwoodonlinejournals. com/index.php/jarce/article/view/78

Faure E, Kitchener AC (2009) An archaeological and historical review of the relationships between felids and people. Anthrozoös 22(3):221238. https://doi.org/10.2752/175303709X457577

Fernandes ICF (2004) O Castelo de Palmela. Do islâmico ao Cristão, Câmara Municipal de Palmela, Palmela

Fernández Ochoa C, Gutiérrez González JA, Orejas Saco del Valle A (2015) Gijón, entre la Antigüedad y la Edad Media. In: Ochoa C (ed) La fábrica de tabacos de Gijón: arqueología e historia de un espacio milenário, Ayuntamiento de Gijòn, Gijòn, pp 282-295 http:/hdl.handle.net/10651/39195

Fernandez P, Bouzouggar A, Collina-Girard J, Coulon M (2015) The last occurrence of Megaceroides algericus Lyddekker, 1890 (Mammalia, Cervidae) during the middle Holocene in the cave of Bizmoune (Morocco, Essaouira region). Quat Int 374:154-167. https://doi. org/10.1016/j.quaint.2015.03.034

Ferràndez-Cañadell C, Ribot F, Gibert L (2014) New fossil teeth of Theropithecus oswaldi (Cercopithecoidea) from the Early Pleistocene at Cueva Victoria (SE Spain). J Hum Evol 74:55-66. https://doi.org/10.1016/j.jhevol.2014.02.020

Garcea EA (2004) Crossing deserts and avoiding seas: Aterian north African-European relations. J Anthropol Res 60(1):27-53. https:// doi.org/10.1086/jar.60.1.3631007

Garcia J, Landeck G, Martínez K, Carbonell E (2013) Hominin dispersals from the Jaramillo subchron in central and South-Western Europe:
Untermassfeld (Germany) and Vallparadís (Spain). Quat Int 316:73 93. https://doi.org/10.1016/j.quaint.2013.03.005

Gaubert P (2016) Fate of the Mongooses and the Genet (Carnivora) in Mediterranean Europe: None native, all invasive? In: Angelici FM, problematic wildlife, Springer, Cham, pp 295-314. https://doi.org/ 10.1007/978-3-319-22246-2_14, 2016

Gaubert P, Machordom A, Morales A, López-Bao JV, Veron G, Amin M, Barros T, Basuony M, Djagoun C, Linh San E, Fonseca C, Geffen E, Ozkurt SO, Cruaud C, Couloux A, Palomares F (2011) Comparative phylogeography of two African carnivorans presumably introduced into Europe: disentangling natural versus human-mediated dispersal across the strait of Gibraltar. J Biogeogr 38(2):341-358. https://doi. $\operatorname{org} / 10.1111 / j .1365-2699.2010 .02406 . x$

Geraads D (2008) Plio-Pleistocene Carnivora of northwestern Africa: a short review. Comptes Rendus Palevol 7(8):591-599. https://doi. org/10.1016/j.crpv.2008.09.008

Geraads D (2010) Biogeographic relationships of Pliocene and Pleistocene north-western African mammals. Quat Int 212(2): 159 168. https://doi.org/10.1016/j.quaint.2009.06.002

Geraads D, Alemseged Z, Reed D, Wynn J, Roman DC (2004) The Pleistocene fauna (other than primates) from Asbole, lower Awash Valley, Ethiopia, and its environmental and biochronological implications. Geobios 37(6):697-718. https://doi.org/10.1016/j.geobios. 2003.05.011

Geraads D, Raynal JP, Sbihi-Alaoui FZ (2010) Mammalian faunas from the Pliocene and Pleistocene of Casablanca (Morocco). Hist Biol 22(1-3):275-285. https://doi.org/10.1080/08912960903458011

Gibert J, Gibert L, Iglesias A (2003) The Gibraltar Strait: a Pleistocene door of Europe? Hum Evol 18(3-4):147-160. https://doi.org/10. 1007/BF02436283

Gibert L, Scott GR, Scholz D, Budsky A, Ferrandez C, Ribot F, Marín RA, Lería M (2016) Chronology for the Cueva Victoria fossil site (SE Spain): evidence for early Pleistocene afro-Iberian dispersals. $\mathbf{J}$ Hum Evol 90:183-197. https://doi.org/10.1016/j.jhevol.2015.08. 002

Goodall-Copestake WP, Tarling GA, Murphy EJ (2012) On the comparison of population-level estimates of haplotype and nucleotide diversity: a case study using the gene cox 1 in animals. Heredity 109(1):50-56. https://doi.org/10.1038/hdy.2012.12

Gracia FJ, Rodríguez-Vidal J, Cáceres LM, Belluomini G, Benavente J, Alonso C (2008) Diapiric uplift of an MIS 3 marine deposit in SW Spain: implications for Late Pleistocene Sea level reconstruction and palaeogeography of the strait of Gibraltar. Quat Sci Rev 27(23-24): 2219-2231. https://doi.org/10.1016/j.quascirev.2008.08.013

Gutscher MA (2005) Destruction of Atlantis by a great earthquake and tsunami? A geological analysis of the Spartel Bank hypothesis. Geology 33(8):685-688. https://doi.org/10.1130/G21597AR.1

Hänfling B, Carvalho GR, Brandl R (2002) Mt-DNA sequences and possible invasion pathways of the Chinese mitten crab. Mar Ecol Prog Ser 238:307-310. https://doi.org/10.3354/meps238307

Harrison DL (1968) The mammals of Arabia. Ernst Benn Limited, London

Heras Mora FJ, Olmedo Gragera AB Pérez Maestro C (2017) Dinámica urbana en el Suburbio Norte de Augusta Emerita. Síntesis diacrónica de las excavaciones en el llamado Corralón de los Blanes. In: Mérida, Excav. Arqueol. 12, vol. 2, Mérida

Heras Mora FJ, Bustamante Álvarez M, Olmedo Gragera AB (2011) El vertedero de suburbio norte de Augusta Emerita. Reflexión sobre la dinámica topográfica en el solar de la $\mathrm{C} /$ Almendralejo $n^{\circ} 41$. In: Remolá JA, Acero, J (eds) La gestión de residuos urbanos en Hispania, Xavier Dupré Raventós (1956-2006), in memoriam, Mérida, pp. 345-418

Heras Mora FJ, Bustamante Álvarez M, Detry C (in press) Banquete y sacrificio ritual en Augusta Emerita (Mérida, España). Analizando prácticas de posible ascendencia púnica. In: Proceedings X Coloquio Internacional del Centro de 
Estudios Fenicios y Púnicos. Mare Sacrum. Religión, cultos y rituales fenicios en el Mediterráneo. Homenaje al profesor José María Blázquez (Cádiz, 13-15 december 2017)

Heras Mora J, Olmedo AB (2010) Dos nuevos monumentos funerarios en Augusta Emerita. Primer avance de los resultados de la intervención de la calle Almendralejo $n^{\circ} 41$, Mérida (Badajoz, España). Bollettino di Archeologia on line I:45-53

Hinton H, Dunn A (1967) Mongooses. Their natural history and behaviour. University of California Press, Berkeley

Holsinger KE, Weir BS (2009) Genetics in geographically structured populations: defining, estimating and interpreting F ST. Nat Rev Genet 10(9):639-650. https://doi.org/10.1038/nrg2611

Jiménez-Arenas JM, Santonja M, Botella M, Palmqvist P (2011) The oldest handaxes in Europe: fact or artefact? J Archaeol Sci 38(12): 3340-3349. https://doi.org/10.1016/j.jas.2011.07.020

Johnson JR, Thomson RC, Micheletti SJ, Shaffer HB (2011) The origin of tiger salamander (Ambystoma tigrinum) populations in California, Oregon, and Nevada: introductions or relicts? Conserv Genet 12(2):355-370. https://doi.org/10.1007/s10592-010-0144-2

Krijgsman W, Hilgen FJ, Raffi I, Sierro FJ, Wilson DS (1999) Chronology, causes and progression of the Messinian salinity crisis. Nature 400(6745):652 655. https://doi.org/10.1038/23231

Kurten B (1968) Pleistocene mammals of Europe. Weindenfeld \& Nicolson,

Lalis A, Leblois R, Liefried S, Ouarour A, Reddy Beeravolu C, Michaux J, Hamani A, Denys C, Nicolas V (2016) New molecular data favour an anthropogenic introduction of the wood mouse (Apodemus sylvaticus) in North Africa. J Zool Syst Evol Res 54(1):1-12. https://doi.org/10.1111/jzs.12111

Linstädter J, Eiwanger J, Mikdad A, Weniger GC (2012) Human occupation of Northwest Africa: a review of middle Palaeolithic to Epipalaeolithic sites in Morocco. Quat Int 274:158-174. https:// doi.org/10.1016/j.quaint.2012.02.017

Llorente-Rodríguez L, Nores-Quesada C, Gaubert P., Morales-Muñiz, A. (2015). ¿Nativo o foráneo? El meloncillo de Tabacalera y su aportación a la historia de la especie. Ochoa C (ed) La fábrica de tabacos de Gijón: arqueología e historia de un espacio milenário, Ayuntamiento de Gijòn, Gijòn, pp 246-251

Loget N, Jean Van Den Driessche JV (2006) On the origin of the strait of Gibraltar. Sediment Geol 188:341-356. https://doi.org/10.1016/j. sedgeo.2006.03.012

Leitch V (2013) Reconstructing history through pottery: the contribution of Roman N African cookwares. J Roman Archaeology 26:281306. https://doi.org/10.1017/S1047759413000160

Masseti M (2009) The mongoose of the cave of Nerja, southern Spain, is not the oldest Egyptian mongoose of Europe. Archaeofauna 18:65 68

Masseti M, Albarella U, De Grossi Mazzorin J (2010) The crested porcupine, Hystrix cristata L., 1758, in Italy. Anthropozoologica 45(2): $27-42$

Modolo L, Salzburger W, Martin RD (2005) Phylogeography of barbary macaques (Macaca sylvanus) and the origin of the Gibraltar colony. Proc Natl Acad Sci U S A 102(20):7392-7397

Morales J, Pickford M (2008) Creodonts and carnivores from the middle Miocene Muruyur formation at Kipsaraman and Cheparawa, Baringo District, Kenya. Comptes Rendus Palevol 7(8):487-497. https://doi.org/10.1016/j.crpv.2008.09.011

Morales-Muñiz A (1994) Earliest genets in Europe. Nature 370(6490): 512-513. https://doi.org/10.1038/370512b0

Muirhead JR, Gray DK, Kelly DW, Ellis SM, Heath DD, MacIsaac HJ (2008) Identifying the source of species invasions: sampling intensity vs. genetic diversity. Mol Ecol 17(4):1020-1035. https://doi. org/10.1111/j.1365-294X.2008.03669.x

Muttoni G, Scardia G, Kent DV (2018) Early hominins in Europe: the Galerian migration hypothesis. Quat Sci Rev 180:1-29. https://doi. org/10.1016/j.quascirev.2017.10.031
Nicholson PT, Ikram S, Mills S (2015) The catacombs of Anubis at north Saqqara. Antiquity 89(345):645-661. https://doi.org/10.15184/aqy. 2014.53

Niveau AM, Mariñas VY (2006) Banquetes rituales en la necrópolis púnica de Gadir. Gerión 24(1):35-64

O'Regan HJ (2008) The Iberian Peninsula-corridor or cul-de-sac? Mammalian faunal change and possible routes of dispersal in the last 2 million years. Quat Sci Rev 27(23-24):2136-2144. https://doi. org/10.1016/j.quascirev.2008.08.007

Osborn DJ, Helmy I (1980) The contemporary land mammals of Egypt (including Sinai). Fieldiana Zoology 5:1-579

Palomares F, Delibes M (1993) Resting ecology and behaviour of Egyptian mongooses (Herpestes ichneumon) in southwestern Spain. J Zool 230(4):557-566

Palombo MR (2014) Deconstructing mammal dispersals and faunal dynamics in SW Europe during the quaternary. Quat Sci Rev 96:50 71. https://doi.org/10.1016/j.quascirev.2014.05.013

Peigné S, de Bonis L, Mackaye HT, Likius A, Vignaud P, Brunet M (2008) Late Miocene Carnivora from Chad: Herpestidae, Viverridae and small-sized Felidae. Comptes Rendus Palevol 7(8): 499-527. https://doi.org/10.1016/j.crpv.2008.10.002

Petter G (1987) Small carnivores (Viverridae, Mustelidae, Canidae) from Laetoli. In: Leakey M, Harris J (eds) Laetoli: a Pliocene site in northern Tanzania. Clarendon Press, Oxford, pp 194-234

Phillips JD, Gwiazdowski RA, Ashlock D, Hanner R (2015) An exploration of sufficient sampling effort to describe intraspecific DNA barcode haplotype diversity: examples from the ray-finned fishes (Chordata: Actinopterygii). DNA Barcodes 3(1):66-73. https://doi. org/10.1515/dna-2015-0008

Pires AE, Detry C, Fernandez-Rodriguez C, Arruda AM, De Grossi Mazzorin J, Valenzuela S, Ollivier M, Hänni C, Simões F, Ginja C (2017) Roman dogs from the Iberian Peninsula and the Maghreb - a glimpse into their morphology and genetics. Quat Int 471: 132-146. https://doi.org/10.1016/j.quaint.2017.11.044

Prados F (2008) Arquitectura púnica. In: Los monumentos funerarios. Anejos de AEspA XLIV, Madrid

Raynal JP, Sbihi-Alaoui FZ, Mohib A, El Graoui M, Lefèvre D, Texier JP, Geraads D, Hublin JJ, Smith T, Tafforeau P, Zouak M, Grün R, Rhodes EJ, Eggins S, Daujeard C, Fernandes P, Gallotti R, Hossini S, Quefflec A (2010) Hominid cave at Thomas quarry I (Casablanca, Morocco): recent findings and their context. Quat Int 223:369-382. https://doi.org/10.1016/j.quaint.2010.03.011

Reimer PJ, Bard E, Bayliss A, Beck JW, Blackwell PG, Bronk Ramsey C, Buck CE, Cheng H, Edwards RL, Friedrich M, Grootes PM, Guilderson TP, Haflidason H, Hajdas I, Hatté C, Heaton TJ, Hogg AG, Hughen KA, Kaiser KF, Kromer B, Manning SW, Niu M, Reimer RW, Richards DA, Scott EM, Southon JR, Turney CSM, van der Plicht J (2013) IntCall3 and MARINE13 radiocarbon age calibration curves 0-50000 years calBP. Radiocarbon, 55(4): 1869 1887. doi: https://doi.org/10.2458/azu js rc.55.16947

Riquelme-Cantal JA, Simón-Vallejo MD, Palmqvist P, Cortés-Sánchez M (2008) The oldest mongoose of Europe. J Archaeol Sci 35(9):24712473. https://doi.org/10.1016/j.jas.2008.03.015

Rohling EJ, Foster GL, Grant KM, Marino G, Roberts AP, Tamisiea ME, Williams F (2014) Sea-level and deep-sea-temperature variability over the past 5.3 million years. Nature 508(7497):477-482. https:// doi.org/10.1038/nature 13230

Rolland N (2013) The Early Pleistocene human dispersals in the CircumMediterranean Basin and initial peopling of Europe: single or multiple pathways? Quat Int 316:59-72. https://doi.org/10.1016/j. quaint.2013.06.028

Santonja M, Pérez-González A (2010) Mid-Pleistocene Acheulean industrial complex in the Iberian Peninsula. Quat Int 223:154-161. https://doi.org/10.1016/j.quaint.2010.02.010

Santonja M, Pérez-González A, Panera J, Rubio-Jara S, Méndez-Quintas E (2016) The coexistence of Acheulean and ancient middle 
Palaeolithic techno-complexes in the middle Pleistocene of the Iberian Peninsula. Quat Int 411:367-377. https://doi.org/10.1016/j. quaint.2015.04.056

Scheidel W (2014) The shape of the Roman world: modelling imperial connectivity. J Roman Archaeology 27:7-32. https://doi.org/10. 1017/S1047759414001147

Shackleton JC, Van Andel TH, Runnels CN (1984) Coastal paleogeography of the central and western Mediterranean during the last 125 , 000 years and its archaeological implications. J Field Archaeol 11(3):307-314. https://doi.org/10.1179/009346984791535476

Sharon G (2011) Flakes crossing the straits? Entame flakes and northern Africa-Iberia contact during the Acheulean. Afr Archaeol Rev 28(2):125-140. https://doi.org/10.1007/s10437-011-9087-3

Sharon G, Barsky D (2016) The emergence of the Acheulian in EuropeA look from the east. Quat Int 411:25-33. https://doi.org/10.1016/j. quaint.2015.11.108

Silva AM, Boaventura R, Pimenta J, Detry C, Cardoso JL (2014) Perscrutando Espólios antigos: a gruta de Pedra Furada 1 (Vila Franca de Xira). Estudos Arqueológicos de Oeiras 21:159-182

Soares J (2013) Sal e conchas na Pré-História portuguesa O povoado da Ponta da Passadeira (estuário do Tejo). Setúbal Arqueológica-Préhistória das Zonas Húmidas Paisagens de Sal 14:171-196

Soria-Boix C, Donat-Torres MP, Urios V (2017) Contacts in the last 90, 000 years over the strait of Gibraltar evidenced by genetic analysis of wild boar (Sus scrofa). PLoS One 12(7):e0181929. https://doi. org/10.1371/journal.pone. 0181929

Straus LG (2001) Africa and Iberia in the Pleistocene. Quat Int 75:91102. https://doi.org/10.1016/S1040-6182(00)00081-1

Van der Made J (2011) Biogeography and climatic change as a context to human dispersal out of Africa and within Eurasia. Quat Sci Rev 30(11-12):1353-1367. https://doi.org/10.1016/j.quascirev.2010.02. 028

Vázquez de la Cueva A (1985) Sigillata africana en Augusta Emerita. Monografias emeritenses, Mérida

Walker MJ, López-Martínez M, Carrión-García JS, Rodríguez-Estrella T, Del-Toro MSN, Schwenninger JL, López-Jiménez A, OrtegaRodrigáñez J, Haber-Uriarte M, Polo-Camacho J-L, García-Torres J, Campillo-Bo M, Avilés-Fernández A, Zack W (2013) Cueva Negra del Estrecho del Río Quípar (Murcia, Spain): a late Early Pleistocene hominin site with an "Acheulo-LevalloisoMousteroid" Palaeolithic assemblage. Quat Int 294:135-159. https://doi.org/10.1016/j.quaint.2012.04.038

Werdelin L, Dehghani R (2011) Carnivora. In: Harrison T (ed) Paleontology and geology of Laetoli: human evolution in context. Springer, Dordrecht, pp 189-232. https://doi.org/10.1007/978-90-481-9962-4_8

Wood R (2015) From revolution to convention: the past, present and future of radiocarbon dating. J Archaeol Sci 56:61-72. https://doi. $\operatorname{org} / 10.1016 /$ j.jas.2015.02.019 